\title{
Are Commercial Agent Banking Services Worthwhile For Financial Inclusion?
}

\author{
Md. Imran Hossain \\ Department of Finance, \\ Jagannath University, Dhaka-1100, Bangladesh. \\ E-mail: jnuimran@gmail.com. \\ Md. Al-Amin \\ Department of Finance and Banking, \\ Comilla University, Comilla, Bangladesh. \\ E-mail: mohammad.alamin.cuu@gmail.com
}

\author{
Md Abu Toha (Corresponding author) \\ Department of Accounting and Information Systems \\ Business Studies Group \\ National University, Gazipur-1704, Bangladesh. \\ E-mail: abutoha.jnu@gmail.com
}

Received: October 6, 2021 Accepted: October 26, $2021 \quad$ Published: October 28, 2021

doi:10.5296/bms.v12i2.19070ＵRL: https://doi.org/10.5296/bms.v12i2.19070

\begin{abstract}
In recent times, commercial agent banking services have got considerable attention from academia and the banking industry for accelerating financial inclusion in emerging economies. However, it's incomprehensible to accelerate the economic progression through financial inclusion while ignoring a huge segment of the nonbank people from unprivileged areas. A very few studies have been conducted on the association between agent banking services and financial inclusion in emerging economies such as Bangladesh. The present
\end{abstract}


study aims to investigate the impact of agent banking services provided by commercial banks on financial inclusion. To begin with the investigation, this study was based on agency theory considering the purposive sampling technique. This quantitative study was conducted on 19 commercial banks which are currently providing agent banking services in Bangladesh. An econometric model was proposed whereas the dependent construct has one specific dimension named as financial inclusion proxy by several accounts as a percentage of the adult population, in contrast, the independent construct had three dimensions named as-deposited amount, credited amount, and inward remittance of agent bank. In addition to that, this econometric model was based on secondary data whereas data analysis was conducted by considering panel data statistical method using GRETL (2019) software. This statistical analysis revealed that currently both the deposited amount and credited amount do have a significant impact on financial inclusion. It has also been inferred that using agent banking for in-warding remittance and new accounts open by clients have a positive significant relationship with financial inclusion. It is argued that agent banking services by comprising unbanked people in financial inclusion will ultimately prompt the opportunity for proper mobilization of resources and funds while maintaining safety and security. Further, it is also claimed that this study would assist to illustrate the present performance of agent banking services in financial inclusion from a multidimensional perspective which will contribute to providing some more innovative and sustainable products and services towards the unbanked people. Finally, this study recommends that commercial banks through agent banking should include a maximum number of nonbank populations into the financial inclusion by ensuring sustainable agent banking services which will accelerate the emerging economics Sustainable Development Goal (SDGs) performance.

Keywords: financial inclusion, financial services, marginal people/unbanked people, comprehensive growth, sustainable economic development

\section{Introduction}

Recently, policymakers are increasingly recognizing the significance of financial inclusion as a driver for economic and social development. There is hence a crucial prerequisite to formulating national policies that address the detailed challenges of financial inclusion that each nation will be facing. It confirms that financial inclusion is one of the most crucial elements in reducing household economic vulnerability, boosting economic development, eradicating poverty, and improving people's quality of life (Christen, Lauer, Lyman, \& Rosenberg, 2012). Banks can play a critical role in increasing the rate of financial inclusion in the economy by offering financial services to the poorer members of society. Because of their contribution to the economy, an economy cannot function without the rural population. For that reason, financial inclusion is that tool that can confirm the availability of financial services to the deprived populations of the society at a reasonable and minimum cost. According to (Mbugua, 2015) financial inclusion refers to a person's or a group's ability to get a range of financial services that are timely provided, reasonably priced, and convenient. 
Bangladesh is mostly dependent on agriculture, and the majority of the population is involved in agriculture and agro-related activities; also, they reside in nonbank rural areas with inadequate infrastructure. It is often difficult for a commercial bank to provide financial services to the country's rural residents since the expense of operating a branch bank cannot be compensated by the volume of transactions and amount of money transacted by the rural population (Muasya \& Kerongo, 2015; Mwende \& Ngahu, 2016) Most of the people cannot get the proper financial services from the conventional banks even they are not acquainted with different financial activities of banks offering to them.

In a nutshell, the introduction of agent banking services gives them the hope of getting banking services. According to Bangladesh Bank (2013) providing banking services on a limited scale to the deprived class of people of the society through agents appointed by valid agreement instead of a teller/cashier is called agent banking. It is like an outlet that provides services like deposit collection and withdrawal facility, funds transfer facility, collections of bills, etc on behalf of a bank (Mahmood \& Sarker, 2015). That's the reason it is called agent banking. Moreover, the number of clients of agent banking is significantly increasing every year. Studies show that agent banking is playing a vital role in financial inclusion worldwide by including those numbers of people those were excluded by branch banking (Amidžic, Massara, \& Mialou, 2014; Demirgüç-Kunt, Klapper, Singer, \& Van Oudheusden, 2015; Hannig \& Jansen, 2010; Waihenya, 2012)

In 2009, Kenya's Central Bank began taking steps to establish alternative banking channels through brokers who are not bank employees. The Banking Act has been amended to allow banks to hire agents to provide financial services. Small agent outlets, such as small stationery, fuel stations, medicine stores, and other retail areas, were found to have a significant impact on developing access to financial services, particularly in rural areas, resulting in the growth of numerous agency banks across the country, according to the report (Baron \& Staten, 2002). According to (Abebe, 1995; Bhawuk, Mrazek, \& Munusamy, 2017; Harvey, Lefebvre, \& Lefebvre, 1997), stating that banking agents need flexible retail organization and lesser setting up and operating expenditure for offering poor people of the society for their preliminary access to the field of different financial services. Furthermore, underprivileged individuals frequently feel more satisfied with their banking when they receive services from a doorstep shop rather than traveling to a branch. (Machin, 2004).

Investigating the variables that influence people's need for credit and savings beyond affordability, as well as the effect of financial inclusion on poverty. Researchers have looked at the qualities of consumers on inclusion, as well as the characteristics of the micro-institutions and the whole system. Due to the high cost of services, financial goods are generally homogenous and tropical from an organizational standpoint (Gimble, Bunnell, Chiu, \& Guilak, 2011; Lumpkin, 2010; Oral \& Yolalan, 1990). As a consequence, services are not tailored to the diverse financial requirements of livestock producers and consumers, resulting in a significant imbalance between supply and demand. Access to financial services has been experimentally shown to be influenced by collateral circumstances and household 
characteristics such as age, education level, and household head sex. (Fletschner \& Kenney, 2014; Okten \& Osili, 2004).

The majority of studies have focused on the importance, actions, policies, areas, structures, and various products of agent banking. The association between different goods provided to unbanked individuals and financial inclusion via agent banking, on the other hand, has to be investigated. It's critical to investigate the existing performance of agent banking to evaluate its current position and contribution. If this study is disregarded, it will be challenging to take appropriate action in terms of policy and setup modifications, as well as providing various new goods to marginalized and unbanked individuals. Therefore, the present study aims to investigate the impact of agent banking services provided by commercial banks on financial inclusion. In addition to that, there are some additional objectives of this study as follows

- To find out the impact on financial inclusion of consumer cash deposits made by agencies.

- To evaluate the effect on financial inclusion of the number of loan disbursements made by agencies

- To determine the impact on financial inclusion of consumer inward remittance using agencies

- To estimate the influence on financial inclusion of the number of new bank accounts opened by the agencies.

- To appraise the impact on financial inclusion regarding the involvement of the number of banking agencies.

The rest of the paper presents the previous literature review in section 2 , in section 3 the objectives of this paper have been developed based on which in section 4 the research methodology is established. In section 5 the collected data have been tested statistically and section 6 summarizes the results of the analysis. And rest of the chapter discusses the contribution and conclusion of this paper.

\section{Literature Review}

Agent banking is the provision of tailored banking and financial services to the underserved and marginalized people via the use of an agent under a formal agency contract rather than a teller or cashier. The agent who handles financial transactions on behalf of a bank oversees it completely. Agent banking, also known as agency banking, may help businesses grow internationally by allowing them to provide a wide range of services. (Chiteli, 2013; Cull, Gine, Harten, Heitmann, \& Rusu, 2018; Kitaka, 2001) financial institutions are supported by agents in switching their existing entrepreneurs or businessmen from crammed full branches in the course of facilitating an effective and useful channel for cost-effectively getting banking services through the agent banking system. 
(Gardner, Mills, \& Cooperman, 2005; Saunders, Cornett, \& McGraw, 2006) the cost of branch banking is higher than that of agent banking for two reasons. The initial fixed cost is lower than that of branch banking, and the financial agent hired by banks often undertakes self-investment in the development of agent banking facilities' infrastructure.

Some of the early studies have been done by (Dermish, Kneiding, Leishman, \& Mas, 2011; Mahmood \& Sarker, 2015; Mangani, Heatubun, \& Tambunan, 2021) conducted some of the first research in Latin America after the agency banking system was established. According to their research, branchless banking reduces service delivery costs; platforms are mostly used to make client payments, rather than saving or credit; and a lower number of people have started utilizing branchless financial banking services than expected. (Dias \& McKee, 2010) agents will not provide quality service to their targeted customers without ongoing, on-site supervision and in-store training facilities, to ensure that the agents are sufficiently liquid, always branded, and following the prescribed business processes. For this kinds of business operations banks needs proactive rather than reactive which will incerase the firm financial value, further minimize the risk(Akhtar, Khan, \& Khan, 2020; Ali, Johl, \& Excellence, 2021; Jan et al., 2021; Johl \& Toha, 2021; Shad, Lai, \& Management, 2019; Shad \& Lai, 2015).

(Andrieş, 2009) the character of financial mediators may be explained in principle by the existence of a few unique variables. Higher transaction costs, insufficient information when it's required, and the regulatory process are all examples. Despite residing in the city, many slum residents are unable to access financial services, and only a few individuals have bank accounts, according to major research conducted in Mumbai's slums. It was shocking to learn that none of the respondents had a private bank account. As a result, the role of private banks in financial inclusion must be expanded, and scenarios must be prioritized for reform to guarantee that more unbanked individuals participate in a financial activity (Bhatia \& Chatterjee, 2010).

According to (Gandhi, 2013) the area of financial inclusion can be explained in many ways. The voluntary effort taken by the banking community to provide agent banking services to the unbanked people is suggested by one alternative. (Atandi, 2013), the reason for this study was to explore the challenges that are facing equity agent banking in West Pokot. The prime objective was to search out the extent to which there has any uncertainty that affects the agent banking system. (Chiteli, 2013) found that expansion in geographic coverage by the 3 commercial banks in Kisumu city succeeded with the involvement of agent banking operations. Technological advancement will play a key role in the appropriate implementation of agent banking operations by commercial banks. Structural development is the most significant challenge to expand financial inclusion in India that's why the various incremental measures are considered by them studied by (Ananth \& Öncü, 2013).

Another study regarding financial Inclusion took place in Hooghly, found that almost $50 \%$ of people who are especially agricultural workers and minority communities living below the poverty line and also illiterate were mostly excluded from the banking system and it's very common in the Indian scenario studied by (Majumdar \& Gupta, 2013). India is one of the 
fastest-growing economies in the world but one-third percent of the world's poor people live here. Here, agriculture activities are their main business. So, there is ample scope to provide varied agency banking services across different places and over time founded by (Chakravarty \& Pal, 2013). World Economic Forum has published the Global Competitiveness Report 2012 wherein they indicate that in 2012, the Central Bank of Malaysia has started agent banking that has been contributed to the agenda of financial inclusion by ensuring the convenience to excellence and inexpensive financial services, predominantly in the unbanked and isolated areas.

(Ndungu \& Njeru, 2014) have explored that to ensure the transformation of agency banking services in Kenya, some important factors have to be considered. One is system availability and the other is reliability. Here, system availability is necessary for ensuring the proper services and reliability helps to increase the conversion of agency banking founded by the study. (Dhillon \& Mittal, 2016) has also studied that less availability of banking services towards marginal farmers is one of the biggest impediments for ensuring social growth and development.

(Barasa \& Mwirigi, 2013) have incorporated descriptive data to measure the weight of the factors. Through agency banking, it is undoubtedly attainable to provide almost all banking services with a minimum formal appearance. Further, they found that the agency banking model has efficiently supported both low-income earning people and given assurance about the financial security of marginal savings of poor people. In this perspective, (Ongore \& Kusa, 2013) indicates that by mobilizing capital for productive activities, banks play a vital role in efficiently allocating countries' assets through their intermediation function whereas agency banking has the ability also to provide banking services to regions where it is almost not possible for banks to access due to having some constraints.

Financial inclusion is that tool that can confirm the availability of financial services to the deprived populations of the society at a reasonable and minimum cost. It leads to ensuring the sustainable economic growth of a country. According to (Christen et al., 2012), records show that financial inclusion helps to reduce the financial backward of unbanked people, ensuring economic and sustainable development, reducing the poverty rate, and increasing the people's living standards.

(Datta \& Singh, 2019; Lenka \& Bairwa, 2016; Zulkhibri, 2016) have conducted research wherein they try to address the necessity of financial inclusion for ensuring the growth of society and economy of a country and especially try to examine the present situation of financial inclusion in the Indian economy. (Dangi \& Kumar, 2013) has studied similar research carried out in India and observed that there have some specific obstacles regarding financial inclusion. These are related to mental and cultural barriers, legal status, level of income, lack of proper learning, way of living, occupation nature and customer's inclination. These results were supported by another research which has been conducted by (Laurine \& Le Roux, 2012) wherein they have also acknowledged the obstacles to financial inclusion. One is socio-economic factors that are: financial literacy, low level of wages and geographical 
situation and another is strict account opening requirements factors that are: document's identification and residential proof for opening an account and further is consideration of product designing that are: high or minimum balance in account and account maintaining cost with bank service charges for the customers.

According to (Cohen, 2002; OHEN, 2009) the global is experiencing a high-tech telecommunications infrastructure that ensures the accessibility of modern technology services which has a great influence on every industry, especially rising industry. It has been predictable that the model of agency banking will play a crucial and inevitable role through a rapidly changing technological environment.

The majority of the Bangladeshi people directly or indirectly depend on agriculture and agro-related activities, furthermore, they live in a very rural area where the infrastructure is not really up to the mark for that reason most of the people cannot get the proper financial services from the conventional banks even they are not acquainted with different financial activities of banks offering to them. Further reaching these unbanked clients in rural areas through establishing a full set-up branch is almost impossible and often costly for financial institutions as the number of financial transactions does not cover the expenditure of a branch (Mbugua, 2015; Muasya \& Kerongo, 2015; Mwende \& Ngahu, 2016). So, intending to expand the financial services to the unbanked community, costs to banks involved in opening a new branch in remote rural areas are a prime impediment.

According to Bangladesh Bank (BB) Economic Trend, March 2017, BB has taken the aforementioned steps to attain financial inclusion through making different banking services offered at the door of un-served and un-banked population and the poor segment of the society staying in the remote location around the country. If the country enables to capture the total population under the banking system, this will bring a constructive impact on the entire economy.

The study is investigating the following five hypotheses which are developed based on the inconclusive result in the literature to achieve the defined goals of establishing Bangladesh's financial inclusion effect of agency banking.

$\mathrm{H}_{1} 1$ : Consumer cash deposits made by Agent banking and financial inclusion are substantially linked

$\mathrm{H}_{1} 2$ : There is no significant relationship between the amount of Loan disbursement made by the agencies and financial inclusion

$\mathrm{H}_{1}$ 3: There is a significant relationship occurs between the number of new accounts opened by the organizations and financial inclusion. 
$\mathrm{H}_{1} 4$ : There is a significant relationship occurs between the number of agencies participating and financial inclusion.

$\mathrm{H}_{1} 5$ : There is a significant relationship between the amount of inward remittance made by the agencies and financial inclusion.

\section{Research Methodology and Data Collection}

\subsection{Research Design}

The theoretical structure based on which the overall research is conducted is called research design. Research design is an organized investigation in which the author has no straight control over the variables as their appearance has already happened (Mugenda \& Mugenda, 1999). As because all the data that have been used in this research is secondary, in this research the authors designed their research work based on panel data analysis to explore the study variables without altering or changing any of them in an attempt to understand them. The impact of agent banking services provided by commercial banks on financial inclusion in Bangladesh is well defined and clarified. The secondary information is gathered from Bangladesh's Central Bank.

\subsection{Target Population and Sampling Size}

Population or universe means the whole mass of observations, which is the parent group from which a sample is to be created, according to (Singh, 2006). In this research, all the 60 commercial banks in Bangladesh as on $30^{\text {th }}$ June, 2020 is considered.

\section{Sampling Size}

In this analysis 19 banks with at least one to five years of adoption and service of the agency banking model.

\subsection{Data Collection Procedure}

As a regulatory authority of any country central bank gets all the financial data from the scheduled commercial banks periodically, as thus Bangladesh Bank also gets all the financial data from all the banks which helps the authors to collect secondary data of financial inclusion of selected 19 banks between 2016 to 2019. This secondary documents are verified and audited, therefore, future investors can relie on them (M. Toha, Johl, \& Khan, 2020; M. A. Toha, Rahman, \& Datta, 2015; Uddin, Toha, \& Faruq, 2020). It is a mandatory requirement from Bangladesh Bank to all the commercial banks that provide agent banking services that, it must provide all the information regarding agent banking services to the Bangladesh Bank.

\subsection{Data Processing and Analysis}

The data was recorded, cleaned, and coded using an Excel spreadsheet. Then it was analyzed by Gretl 2019, and used to predict the dependent variable based on the covariance with the 
concerned independent variables by Using the OLS method. Though the correlation examines the degree of interaction between several variables under contemplation, the regression shall estimate the relationship between dependent and independent variables where financial inclusion is the dependent variable and the independent variables are separate attributes of agency banking. The regression model shall be analyzed in panel data in the following form:

$\mathrm{Y}=\beta 0+\beta 1 \mathrm{X} 1+\beta 2 \mathrm{X} 2+\beta 3 \mathrm{X} 3+\beta 4 \mathrm{X} 4+\varepsilon$

Where: Y- Financial Inclusion (Number of accounts as a \% of the adult population)

$\beta 0$-The regression constant,

$\beta 1-\beta 4$ - Regression coefficient indicating the various levels of importance.

X1- Customer deposits realized through agency banking per quarter for each bank.

X2-Inward remittance payments by customers through agency banking per quarter for each bank.

X3- Loan disbursement through agency banking per month for each bank.

X4- Number of agencies engaged per month for each bank.

$\varepsilon$-Error term

It can be said that the given formula indicates that commercial banks ' financial inclusion (dependent variable) can be expressed as a linear function consisting of one or more independent variables and a random measurement error that accounts for other factors not addressed. The proper analysis shall be done to ensure that the model follows the standard linear regression assumptions. Other findings include homoscedasticity testing and multi-co-linearity testing (Gujarati, Porter, \& Gunasekar, 2012).

The data should conform to the assumption of OLS (Ordinary Least Squared) for regression analysis. The series needs to be stationary; Data from panel data is non-stationary at the time and leads to high R2 with large standard deviation errors and insignificant coefficients. The Augmented Dickey-Fuller ADF test is used for stationary analysis, while the residual histogram is used to assess the normality of the variables used with Jacque Bera statistics.

\section{Data Analysis}

\subsection{Descriptive Statistics}

The results in table 4.1 indicate the mean and median of financial inclusion are quite equal. Therefore, it can be said that there is an even distribution among the collected data. The Mean and the median of the financial inclusion are respectively 0.0176239 and 0.0154986 which is almost similar. 
Table 5.1. Descriptive Statistics

\begin{tabular}{ccccccc}
\hline Variable & Mean & Median & Minimum & Maximum & Std. Dev. & C.V. \\
\hline FI & 0.0176239 & 0.0154986 & 0.0055182 & 0.0359259 & 1110000 & 0.597627 \\
\hline Opening account & 1860000 & 1590000 & 544536 & 3960000 & 0.00985058 & 0.558933 \\
\hline No of agents & 3537.42 & 3402 & 1646 & 6531 & 1674.93 & 0.473489 \\
\hline Deposit amount & 23600000000 & 18200000000 & 3810000000 & 61700000000 & 19000000000 & 0.802598 \\
\hline Inward remittance & 41400000000 & 30900000000 & 3100000000 & 119000000000 & 37300000000 & 0.900596 \\
\hline Total credits & 1340000000 & 1300000000 & 50000000 & 3060000000 & 906000000 & 0.674321 \\
\hline
\end{tabular}

In this data set, we take six variables from our sample which was 19 commercial banks. Here, we collect quarterly data on agent banking from this commercial bank to find out, how agency banking is helping the economy. For all the variables, the Mean and Median values are not exactly matched but they are very much similar. The total observation is 12 quarters which is three years for the data set.

\subsection{Data Characteristics}

The matrix of correlation was used to examine the linear relationship between variables and to determine the existence of multi-collinearity between the variables of explanation. (Gujarati, 2007) defines multi-collinearity as a perfect or accurate relationship between some or all of the model's explanatory variables. They further indicate that when correlations between two variables are 0.8 and above there is evidence of high multi-collinearity. On the other, if the object of your study is to predict y values, then collinearity is not an issue.

Table 5.2. Correlation matrix for variables

\begin{tabular}{|c|c|c|c|c|c|c|}
\hline \multicolumn{7}{|c|}{ Correlation coefficients, using the observations 1 - 12} \\
\hline \multicolumn{7}{|c|}{$5 \%$ critical value $($ two-tailed $)=0.5760$ for $n=12$} \\
\hline & FI & $\begin{array}{l}\text { Opening } \\
\text { account }\end{array}$ & $\begin{array}{l}\text { No of } \\
\text { agents }\end{array}$ & Deposit amount & $\begin{array}{l}\text { Inward } \\
\text { remittance }\end{array}$ & $\begin{array}{l}\text { Total } \\
\text { credits }\end{array}$ \\
\hline FI & 1 & 0.7988 & 0.6947 & 0.906 & 0.7905 & 0.6875 \\
\hline Opening account & & 1 & 0.7935 & 0.694 & 0.8946 & 0.7832 \\
\hline No of agents & & & 1 & 0.6894 & 0.7868 & 0.6809 \\
\hline Deposit amount & & & & 1 & 0.7979 & 0.7712 \\
\hline $\begin{array}{l}\text { Inward } \\
\text { remittance }\end{array}$ & & & & & 1 & 0.671 \\
\hline Total credits & & & & & & 1 \\
\hline
\end{tabular}

However, from the above all the coefficients of less than .10 between the explaining variables of financial inclusion discussed or very near to the benchmark level, a clear indication of the absence of multicollinearity in the data series thus justifying the use of OLS regression.

As the data series do not have multicollinearity problems, we can run the regression analysis on these data series, as well as the hypothesis test. 


\subsection{Regression Analysis}

This section contains the results of a regression analysis run on financial inclusion as the dependent variable and the other hand. No of people open a new account through agency banking, no of agents, total deposited amount, Inward remittance for that particular period, and total loan distribution are the independent variable of my analysis.

Table 5.3. Regression analysis

\section{Dependent}

variable: FI

\begin{tabular}{|c|c|c|c|c|}
\hline Variable & Coefficient & Std. Error & t-statistic & p-value \\
\hline Const & -0.0002 & 0.000936901 & -0.2284 & 0.82691 \\
\hline Opening account & 0.00000000836 & 0.00000000178 & 4.6883 & 0.00337 \\
\hline No of agents & 0.00000075200 & 0.00000074100 & 2.0155 & 0.00907 \\
\hline Deposited amount & 0 & 0.000000000000116 & -0.0426 & 0.9674 \\
\hline Inward remittance & 0 & 0 & -2.7368 & 0.00903 \\
\hline \multirow[t]{12}{*}{ Total credits } & 0.000000000001220 & 0.000000000000816 & 1.4899 & 0.18684 \\
\hline & \multicolumn{3}{|c|}{ Mean of dependent variable $=0.0176239$} & \\
\hline & \multicolumn{3}{|c|}{ Standard deviation of dep. var. $=0.00985058$} & \\
\hline & \multicolumn{3}{|c|}{ Sum of squared residuals $=1.01072 \mathrm{e}-006$} & \\
\hline & \multicolumn{3}{|c|}{ Standard error of residuals $=0.000410431$} & \\
\hline & \multicolumn{3}{|c|}{ Unadjusted R Square $=0.999053$} & \\
\hline & \multicolumn{3}{|c|}{ Adjusted R Square $=0.998264$} & \\
\hline & \multicolumn{3}{|c|}{ F-statistic $(5,6)=1266.06(p$-value $<0.00001)$} & \\
\hline & \multicolumn{3}{|c|}{ Log-likelihood $=80.7113$} & \\
\hline & \multicolumn{3}{|c|}{ Akaike information criterion $=-149.423$} & \\
\hline & \multicolumn{3}{|c|}{ Schwarz Bayesian criterion $=-146.513$} & \\
\hline & \multicolumn{3}{|c|}{ Hannan-Quinn criterion $=-150.5$} & \\
\hline
\end{tabular}

From the above-mentioned regression table, it is shown that there exists a positive relationship between all the variables and financial inclusion as indicated by the positive coefficients. The t-statistics acquired are greater than 2 in absolute terms other total deposited and total credit amount, which shows an indication that all variables are stationary significant at $5 \%$ other than banking agency engaged. From the analysis, we can see that the value of $r$ square is 0.999053, which shows that there is a strong relationship between dependent variables and independent variables. If any of the value of independent variables changes, then the value of dependent variables also change strongly.

The standard deviation of FI is 0.00985058 and the standard error is 0.00041043 . We know the more data points that are included in the mean measurements; the larger tends to be the typical error. The data is said to be more representative of the true mean when the standard error is small. In cases where the standard error is, there may be some serious anomalies in 
the data. In this research the std. error is relatively small which indicates that no anomalies have occurred in the data series.

\subsection{Normality Test}

From the above figure, we can see that the data are normally distributed as the figure is bell shape. Besides this, the value of $\mathrm{P}$ is 0.52553 , which indicates that the independent variables have no strong relationship among them.

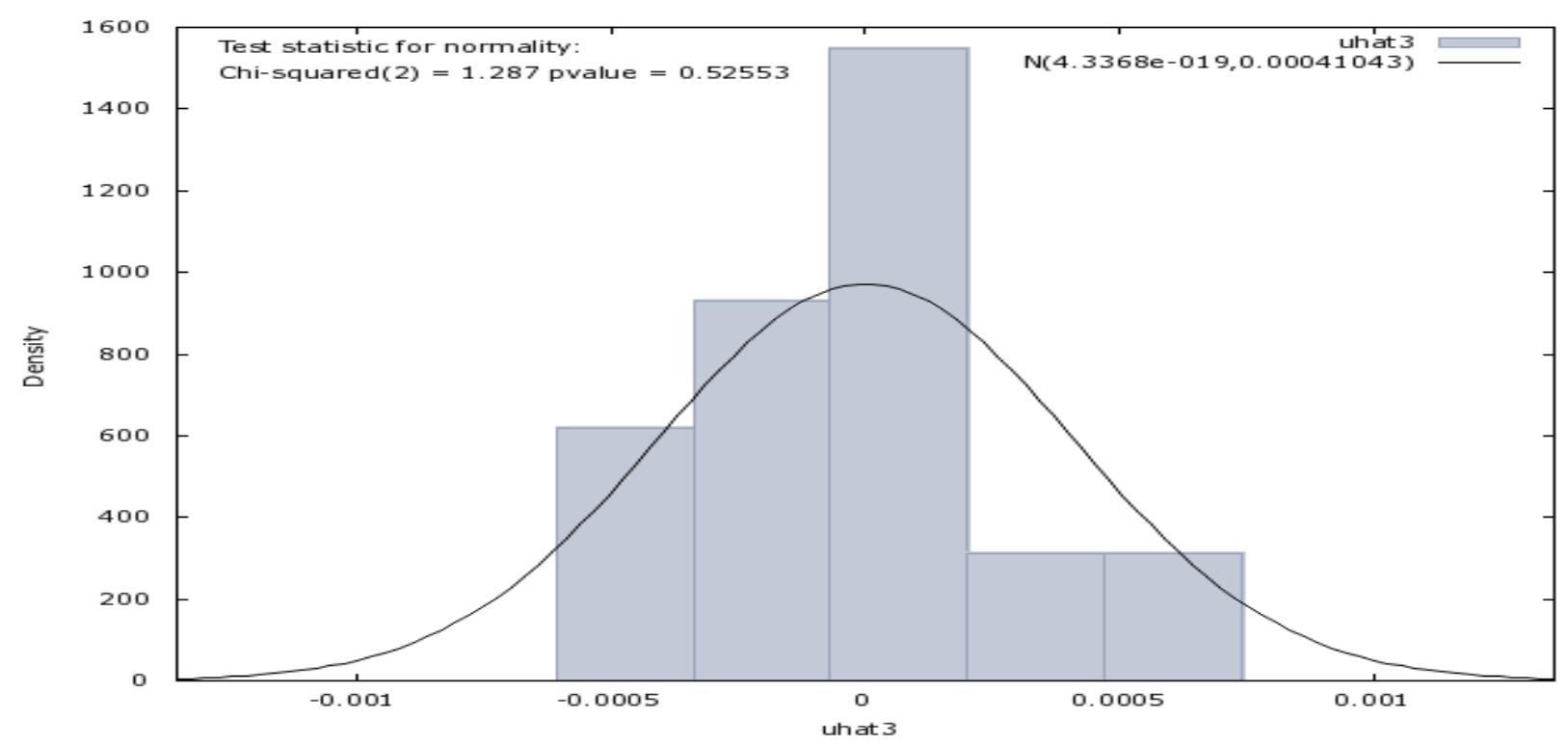

Figure: 1. Normality test.

\subsection{Heteroscedasticity}

This experiment was used to assess the probability of non-constant variation within the data set of the panel. The findings below indicate the presence of heteroscedasticity in the data set since the Observed R-square likelihood had a $\mathrm{P}$ value of 0.3219 exceeding 0.05 indicating that the constant variance null hypothesis was dismissed. It suggested that the error term variability differs from observation to observation.

Table 4. White's test for Heteroscedasticity

\begin{tabular}{lllll}
\hline \multicolumn{1}{c}{ Variable } & Coefficient & STD Error & T-Stat & P-Value \\
\hline Const & -0.00000261000000 & 0.00000235000000 & -1.11 & 0.46677 \\
\hline Opening account & 0.00000000000175 & 0.00000000000171 & 1.022 & 0.49322 \\
\hline No of agents & 0.00000000174000 & 0.00000000209000 & 0.829 & 0.55918 \\
\hline Deposit amount & 0 & 0 & -0.191 & 0.8801 \\
\hline Inward remittance & 0 & 0 & -0.26 & 0.83816 \\
\hline Total credits & 0 & 0 & -1.543 & 0.36614 \\
\hline Sq of Opening ac & 0 & 0 & 0.377 & 0.77046 \\
\hline Sq of No of agent & -0.000000000000311 & 0.000000000000439 & -0.707 & 0.6082 \\
\hline Sq of Deposit & 0 & 0 & 0.404 & 0.75533 \\
\hline
\end{tabular}




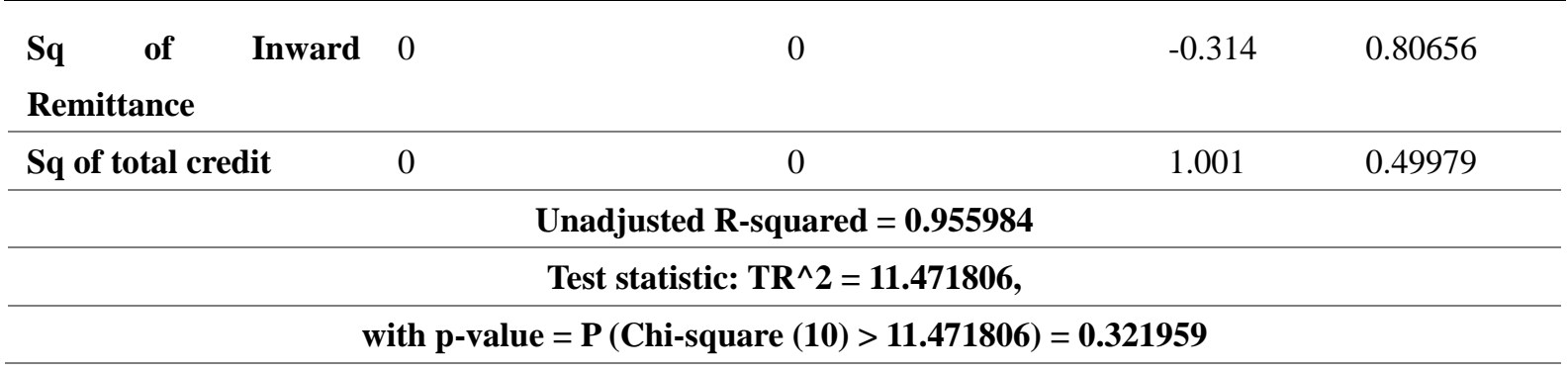

\section{Findings and Discussion}

The data contains financial inclusion as the dependent variable and tries to find out the relationship with other factors which I mentioned as the independent variable. These factors are given such as Cash deposits, The amount of Loan disbursement, New accounts opened by the organizations, the number of agencies participating, Inward remittance made by the agencies. For the analysis, a t-test has been used as a valuation tool because the collected sample is less than 30 . The significance level is $5 \%$.

\subsection{Relationship Between Cash Deposits Made by Agent Banking and Financial Inclusion}

$\mathrm{H}_{1} 1$ : Consumer cash deposits made by Agent banking and financial inclusion are substantially linked.

Table 5. Consumer cash deposits made by Agent banking and financial inclusion

\begin{tabular}{lllll}
\hline & Coefficient & Std. Error & t-ratio & p-value \\
\hline Const & -0.0002 & 0.000936901 & -0.2284 & 0.82691 \\
$\begin{array}{l}\text { Deposited } \\
\text { amount }\end{array}$ & 0 & $1.16 \mathrm{E}-13$ & -0.0426 & 0.9674 \\
\hline
\end{tabular}

Here, the P-value is greater than the significance level as well as the t statistic value is lower than the 2. So the Null hypothesis is accepted. This implies that there is no relationship between deposits made by Agent banking and financial inclusion.

5.2 Relationship between the Amount of Loan Disbursement Made by the Agencies and Financial Inclusion

$\mathrm{H}_{1}$ 2: There is no significant relationship between the amount of Loan disbursement made by the agencies and financial inclusion 
Table 6. between the amounts of Loan disbursement made by the agencies and financial inclusion

\begin{tabular}{lllll}
\hline & Coefficient & Std. Error & t-ratio & p-value \\
\hline Const & -0.0002 & 0.000936901 & -0.2284 & 0.82691 \\
$\begin{array}{l}\text { Total } \\
\text { credits }\end{array}$ & 0.00000000000122 & 0.000000000000816 & 1.4899 & 0.18684 \\
\hline
\end{tabular}

Significance level 0.05

Here, P-value is greater than the significance level and the $t$ statistics value is less than 2 . We know that, if P-value is greater than the significance level then the null hypothesis is accepted, so there is no relationship between the amount of Loan disbursement made by the agencies and financial inclusion

5.3 Relationship Between the Number of New Accounts Opened by the Organizations and Financial Inclusion

$\mathrm{H}_{1}$ 3: There is a significant relationship occurs between the number of new accounts opened by the organizations and financial inclusion.

Table 7. Between the numbers of new accounts opened by the organizations and financial inclusion

\begin{tabular}{lllll}
\hline & Coefficient & Std. Error & t-ratio & p-value \\
\hline Const & -0.0002 & 0.000936901 & -0.2284 & 0.82691 \\
Opening & 0.00000000836 & 0.00000000178 & 4.6883 & 0.00337 \\
account & & & & \\
\hline
\end{tabular}

Significance level 0.05

Here the P-value is less than the significance level. So null hypothesis is rejected and the alternative hypothesis is accepted. We can say that there is significant relationship occurs between the number of new accounts opened by the organizations and financial inclusion 
5.4 Relationship Occurs Between the Number of Agencies Participating and Financial Inclusion

$\mathrm{H}_{1} 4$ : There is a significant relationship occurs between the number of agencies participating and financial inclusion.

Table 8. The number of agencies participating and financial inclusion

\begin{tabular}{lllll}
\hline & Coefficient & Std. Error & t-ratio & p-value \\
\hline Const & -0.0002 & 0.000936901 & -0.2284 & 0.82691 \\
No of agents & 0.000000752 & 0.000000741 & 2.0155 & 0.00907 \\
\hline
\end{tabular}

Significance level 0.05

The results of the regression tests in the table show that t-statistics has 2.0155 which is more than 2 and the probability of 0.00907 which is less than 5 percent of the number of agencies participating and financial inclusion. It means that the null hypothesis is rejected. So it indicates that there is strong relationship occurs between the number of agencies participating and financial inclusion.

5.5 Relationship Between the Amount of Inward Remittance Made by the Agencies and Financial Inclusion

$\mathrm{H}_{01} 5$ : There is a significant relationship between the amount of inward remittance made by the agencies and financial inclusion

Table 9. The amount of inward remittance made by the agencies and financial inclusion

\begin{tabular}{lllll}
\hline & Coefficient & Std. Error & t-ratio & p-value \\
\hline Const & -0.0002 & 0.000936901 & -0.2284 & 0.82691 \\
$\begin{array}{l}\text { Inward } \\
\text { remittance }\end{array}$ & 0 & 0 & -2.7368 & 0.00903 \\
\hline
\end{tabular}

Significance level 0.05

Here, the P-value is less than the significance level. So the alternative hypothesis is accepted. This implies that there is strong relationship occurs between the amount of inward remittance made by the agencies and financial inclusion. 
From the above analysis, it is investigated that there is strong relationship between factors and financial inclusion except deposited and credited amount through agency banking value.

Table 10. Hypothesis summary table

\begin{tabular}{clll}
\hline Hypothesis & T value & P-value & Decision \\
\hline I & -0.0426 & 0.9674 & No relationship \\
\hline II & 1.4899 & 0.18684 & No relationship \\
\hline IV & 4.6883 & 0.00337 & Significant relationship \\
\hline V & 2.0155 & 0.00907 & Significant relationship \\
\hline
\end{tabular}

From the results found above, it is clear that financial inclusion and agency banking has a strong positive relationship. The tests carried out show that the coefficient of correlation between the aspects of agent banking (the independent variables) and financial inclusion (the dependent variable) was 0.57 , which is sufficient to suggest the presence of a strong relationship between the independent variables and the dependent variable.

The R-square (determination coefficient) is 0.998264, which means that the variables of the agency banking dimensions will describe and forecast 99.82 percent of the variability in the financial inclusion parameter. Consequently, the impact of agency banking on inclusive finance cannot be ignored, but all stakeholders should accept it as it is a measure of poverty reduction as well as a way of ensuring income equality. For resource utilization purposes, every government's vision is to have an effective and inclusive financial system. The agent banking model is a system that is constantly evolving and rising, and the level of financial inclusion is increasing proportionately as it develops.

One of the main sources of our govt. is remittance made by people who work outside of the country? Most of them belong to rural areas. My research shows that introduction of agency banking generates more revenue from the remittance because of easy accessibility. People who live in a rural area can easily get the benefit of the banking sector because of agency banking.

\section{Conclusion}

Any government's goal is to achieve financial inclusion for a country's whole population. Governments in developing nations are taking the necessary steps and creating regulatory infrastructure to ensure that agent banking delivers all of the financial services required to satisfy the needs of the excluded. Equitable finance is a complex idea that has evolved greatly 
since its conception. Originally conceived as a means of reducing poverty and boosting income equality, the concept has evolved into a critical component of financial stability and economic progress.

Measuring the nexus between agent banking services and financial inclusion is undoubtedly an important work for us because of its three major reasons. Firstly, the current activities of agent banking services for involving unbanked people in the formal financial channel aid in realizing its contribution to the economy because when more marginal people use the financial channel for financial transactions, it creates the opportunity for proper mobilization of resources and funds while maintaining safety and security. Secondly, this work also aids in assessing the current performance of agent banking services and their significance for financial inclusion, allowing financial institutions to provide more innovative and appropriate goods and services to the unbanked, ensuring the industry's long-term viability. And finally, this effort also aids in understanding the participation of unbanked and marginal people in financial institutions, which is a better indicator of them becoming accustomed to using this formal channel to conduct various monetary transactions, thereby improving their living standards in both urban and rural areas.

Though it has been realized that agent banking has an important role in financial inclusion our analysis has shown a mixed scenario considering five important indicators or parameters. Among these, two parameters explained no significant relationship, and the rest of the three found significant relationships with agent banking. In this circumstance, there is ample opportunity and scope to work in this area because the first two parameters would be significantly related to agent banking along with analyzing more with the rest of the three parameters in a global context.

The studies conclude that to attain the sustainable development goal, it is obvious to include a maximum number of population into the financial channels. Only then the deprived people of the rural areas can develop their living standards as well as economic condition. To facilitate that, agent banking can play a vital role. Therefore, Agent Banking should deliver affordable, open, and acceptable financial products to the previously unbanked and under-banked, to increase financial inclusion. As a precursor to a more robust framework designed to increase access to credit as this is the key to unlocking economic activity in remote areas will also promote and improve unbanked account opening and financial literacy by helping people better appreciate and consumer financial services.

\section{References}

Abebe, A. (1995). Instituting Effective Linkages between Formal and Informal Financial Sector in Africa. A proposal in Savings and Development.

Akhtar, S., Khan, T., \& Khan, P. A. J. J. o. C. R. (2020). Examine the key drivers affecting bottom line: A panel estimation study of Indian commercial bank. 7(9), 2020. https://doi.org/10.31838/jcr.07.09.205 
Ali, K., Johl, S. K. J. T. Q. M., \& Excellence, B. (2021). Soft and hard TQM practices: future research agenda for industry 4.0.1-31.

Amidžic, G., Massara, M. A., \& Mialou, A. (2014). Assessing countries' financial inclusion standing-A new composite index: International Monetary Fund.

Ananth, S., \& Öncü, T. S. (2013). Challenges to financial inclusion in India: The case of Andhra Pradesh. Economic and Political weekly, 77-83.

Andrieş, A. M. (2009). Theories regarding financial intermediation and financial intermediaries-a survey. The USV Annals of Economics and Public Administration, 9(2), 254-261.

Atandi, F. G. (2013). Challenges of agent banking experiences in Kenya. International Journal of Academic Research in Business and Social Sciences, 3(8), 397. https://doi.org/10.6007/IJARBSS/v3-i8/161

Barasa, D. A., \& Mwirigi, F. M. (2013). The role of agency banking in enhancing financial sector deepening in emerging markets: lessons from the Kenyan experience. European Journal of Business and Management, 5(21), 19-21.

Baron, J., \& Staten, M. (2002). The Value of Competitive Credit Reports. In: Cambridge, USA, Mit Press.

Bhatia, N., \& Chatterjee, A. (2010). Financial inclusion in the slums of Mumbai. Economic and Political weekly, 23-26.

Bhawuk, D. P., Mrazek, S., \& Munusamy, V. P. (2017). From Social Engineering to Community Transformation: Amul, Grameen Bank, and Mondragon as Exemplar Organizations 1. In Ethical Transformations for a Sustainable Future (pp. 75-112): Routledge. https://doi.org/10.4324/9781351311403-7

Chakravarty, S. R., \& Pal, R. (2013). Financial inclusion in India: An axiomatic approach. Journal of Policy modeling, 35(5), 813-837. https://doi.org/10.1016/j.jpolmod.2012.12.007

Chiteli, N. (2013). Agent banking operations as a competitive strategy of commercial banks in Kisumu City. International journal of business and social Science, 4(13).

Christen, R. P., Lauer, K., Lyman, T., \& Rosenberg, R. (2012). A guide to regulation and supervision of microfinance: Consensus guidelines. Washington, DC: CGAP.

Cohen, M. (2002). Making microfinance more client-led. Journal of International Development, 14(3), 335. https://doi.org/10.1002/jid.881

Cull, R., Gine, X., Harten, S., Heitmann, S., \& Rusu, A. B. (2018). Agent banking in a highly under-developed financial sector: Evidence from Democratic Republic of Congo. World Development, 107, 54-74. https://doi.org/10.1016/j.worlddev.2018.02.001 


\section{Macrothink}

Dangi, N., \& Kumar, P. (2013). Current situation of financial inclusion in India and its future visions. International Journal of Management and social sciences research, 2(8), 155-166.

Datta, S. K., \& Singh, K. (2019). Variation and determinants of financial inclusion and their association with human development: A cross-country analysis. IIMB Management Review, 31(4), 336-349. https://doi.org/10.1016/j.iimb.2019.07.013

Demirgüç-Kunt, A., Klapper, L. F., Singer, D., \& Van Oudheusden, P. (2015). The global findex database 2014: Measuring financial inclusion around the world. World Bank Policy Research Working Paper(7255). https://doi.org/10.1596/1813-9450-7255

Dermish, A., Kneiding, C., Leishman, P., \& Mas, I. (2011). Branchless and mobile banking solutions for the poor: a survey of the literature. Innovations: Technology, Governance, Globalization, 6(4), 81-98. https://doi.org/10.1162/INOV_a_00103

Dhillon, L., \& Mittal, N. (2016). Inclusive growth and financial inclusion (issues and challenges). American International Journal of Research in Humanities, Arts and Social Sciences, 14(2), 145-150.

Dias, D., \& McKee, K. (2010). Protecting branchless banking consumers: Policy objectives and regulatory options. Focus Note, 64(64), 20.

Fletschner, D., \& Kenney, L. (2014). Rural women's access to financial services: credit, savings, and insurance. Gender in agriculture, 187-208. https://doi.org/10.1007/978-94-017-8616-4_8

Gandhi, M. (2013). Profitable Models for Banks in Financial Inclusion in India. International Journal of Applied Financial Management Perspectives, 2(3), 474-482.

Gardner, M. J., Mills, D. L., \& Cooperman, E. S. (2005). Managing financial institutions: South-Western Pub.

Gimble, J. M., Bunnell, B. A., Chiu, E. S., \& Guilak, F. (2011). Concise review: Adipose-derived stromal vascular fraction cells and stem cells: Let's not get lost in translation. Stem cells, 29(5), 749-754. https://doi.org/10.1002/stem.629

Gujarati, D. N. (2007). Sangeetha. Basic Econometrics.

Gujarati, D. N., Porter, D. C., \& Gunasekar, S. (2012). Basic econometrics: Tata McGraw-Hill Education.

Hannig, A., \& Jansen, S. (2010). Financial inclusion and financial stability: Current policy issues. https://doi.org/10.2139/ssrn.1729122

Harvey, J., Lefebvre, L. A., \& Lefebvre, E. (1997). Flexibility and technology in services: a conceptual model. International Journal of Operations \& Production Management. https://doi.org/10.1108/01443579710157970 
Jan, A. A., Lai, F.-W., Draz, M. U., Tahir, M., Ali, S. E. A., Zahid, M., ... Quantity. (2021). Integrating sustainability practices into islamic corporate governance for sustainable firm performance: from the lens of agency and stakeholder theories. 1-24. https://doi.org/10.1007/s11135-021-01261-0

Johl, S. K., \& Toha, M. A. J. S. (2021). The Nexus between Proactive Eco-Innovation and Firm Financial Performance: A Circular Economy Perspective. 13(11), 1-24. https://doi.org/10.3390/su13116253

Kitaka, P. (2001). A Survey of the use of financial performance indicators by Micro Finance Institutions in Kenya. Unpublished MBA Research Project, University of Nairobi.

Laurine, C., \& Le Roux, P. (2012). Zimbabwe commercial banks liquidity management in the hyperinflation environment. African Journal of Business Management, 6(48), 11787-11796. https://doi.org/10.5897/AJBM12.1314

Lenka, S. K., \& Bairwa, A. K. (2016). Does financial inclusion affect monetary policy in SAARC countries? Cogent Economics \& Finance, 4(1), 1127011. https://doi.org/10.1080/23322039.2015.1127011

Lumpkin, S. (2010). Consumer protection and financial innovation: a few basic propositions. OECD Journal: Financial market trends, 2010(1), 117-139. https://doi.org/10.1787/fmt-2010-5km7k9tp2jxv

Machin, D. (2004). Building the world's visual language: The increasing global importance of image banks in corporate media. Visual communication, 3(3), 316-336. https://doi.org/10.1177/1470357204045785

Mahmood, R., \& Sarker, S. (2015). Inclusive Growth Through Branchless Banking: A Review of Agent Banking and Its Impact. Journal of Economics and Sustainable Development, 6(23), 86-93.

Majumdar, C., \& Gupta, G. (2013). Financial inclusion in Hooghly. Economic and Political weekly, 55-60.

Mangani, K. S., Heatubun, A. B., \& Tambunan, M. E. (2021). Branchless Banking Process In Rural Area: Price And Non-Price Barriers. Journal of Public Administration and Governance, 11(2), 317-330. https://doi.org/10.5296/jpag.v11i2.18816

Mbugua, S. (2015). Role of Agent Banking Services in Promotion of Financial Inclusion in Nyeri Town Kenya. Research Journal of Finance and Accounting, 6(3), 2222-2847.

Muasya, M., \& Kerongo, F. (2015). The Effects of Agency Banking on Access to Financial Services: A Survey of Commercial Banks in Kilindini District. International Journal of Management Research \& Business Strategy, 4(3), 104-118.

Mugenda, O. M., \& Mugenda, A. G. (1999). Research methods: Quantitative and qualitative approaches: Acts press. 
Mwende, J., \& Ngahu, S. (2016). The role of agency banking in growth of banking sector in Kenya: A survey of bank agents in Nairobi County, Kenya. International Journal of Economics, Commerce and Management, 4(4), 1-21.

Ndungu, C. G., \& Njeru, A. (2014). Assessment of factors influencing adoption of agency banking in Kenya: The case of Kajiado north sub county. International journal of business and commerce, 3(8), 91-111.

OHEN, M. C. (2009). Making microfinance more client led. In Microfinance (pp. 163-182): Routledge.

Okten, C., \& Osili, U. O. (2004). Social networks and credit access in Indonesia. World Development, 32(7), 1225-1246. https://doi.org/10.1016/j.worlddev.2004.01.012

Ongore, V. O., \& Kusa, G. B. (2013). Determinants of financial performance of commercial banks in Kenya. International journal of economics and financial issues, 3(1), 237.

Oral, M., \& Yolalan, R. (1990). An empirical study on measuring operating efficiency and profitability of bank branches. European Journal of Operational Research, 46(3), 282-294. https://doi.org/10.1016/0377-2217(90)90002-S

Saunders, A., Cornett, M. M., \& McGraw, P. A. (2006). Financial institutions management: A risk management approach (Vol. 8): McGraw-Hill/Irwin New York.

Shad, M. K., \& Lai, F. W. (2015). A conceptual framework for enterprise risk management performance measure through economic value added.

Shad, M. K., Lai, F.-W. J. I. J. o. B., \& Management. (2019). Enterprise risk management implementation and firm performance: evidence from the Malaysian oil and gas industry. 14(9), 47-53. https://doi.org/10.5539/ijbm.v14n9p47

Singh, Y. K. (2006). Fundamental of research methodology and statistics: New Age International.

Toha, M. A., Rahman, M. A., \& Datta, S. (2015). The Effect of Audit Firm Size \& Abnormal Audit Fees on Independent Auditor's Opinion: Conceptual Framework (Bangladesh Perspective).

Toha, M., Johl, S. K., \& Khan, P. A. (2020). Firm's Sustainability and Societal Development from the Lens of Fishbone Eco-Innovation: A Moderating Role of ISO 14001-2015 $\begin{array}{llll}\text { Environmental Management } & \text { System. } & \text { Processes, } & 8(9),\end{array}$ https://doi.org/10.3390/pr8091152

Uddin, M. S., Toha, M. A., \& Faruq, M. O. (2020). INTERNATIONAL FINANCIAL REPORTING STANDARD (IFRS) FOR SMEs AND ITS IMPACT ON REPORTING QUALITY. 
Waihenya, H. M. (2012). The effect of agent banking on financial inclusion in Kenya. University of Nairobi,

Zulkhibri, M. (2016). Financial inclusion, financial inclusion policy and Islamic finance. Macroeconomics and Finance in Emerging Market Economies, 9(3), 303-320. https://doi.org/10.1080/17520843.2016.1173716

\section{APPENDIX}

List of commercial banks that provides agent banking services

\begin{tabular}{|l|l|}
\hline 1. Bank Asia Ltd. & 11. Midland Bank Ltd. \\
\hline 2. NRB Commercial Bank Ltd. & 12. United Commercial Bank Ltd. \\
\hline 3. Dutch-Bangla Bank Ltd. & 13. The City Bank Ltd. \\
\hline 4. Al-ArafahIslami Bank Ltd. & 14. A B Bank Ltd. \\
\hline 5. Modhumoti Bank Limited & 15. Islami Bank Bangladesh Ltd. \\
\hline 6. Social Islami Bank Ltd. & 16. The Premier Bank Ltd. \\
\hline 7. Standard Bank Ltd. & 17. NRB Bank Ltd. \\
\hline 8. First Security Islami Bank Ltd & 18. BRAC Bank Ltd. \\
\hline 9. Agrani Bank Ltd. & 19. Eastern Bank Ltd. \\
\hline 10. Mutual Trust Bank Ltd. & \\
\hline
\end{tabular}

\section{Copyright}

Copyright for this article is retained by the author(s), with first publication rights granted to the journal.

This is an open-access article distributed under the terms and conditions of the Creative Commons Attribution license (http://creativecommons.org/licenses/by/4.0/). 